\title{
Impact of Sarcocystis Fusiformis Crude Antigen Administration on Innate and Adaptive Immune Responses of Wistar Rats
}

\author{
Original \\ Abeer M. Badr', Asmaa Abd El-Kader', Marwa E. Shabana ${ }^{3}$ Somaya El-Deeb ${ }^{1}$ \\ and Kareem Morsy ${ }^{1,2}$ \\ Article \\ ${ }^{1}$ Department of Zoology, Faculty of Science, Cairo University, Cairo 12613, Egypt \\ ${ }^{2}$ Department of Biology, College of Science, King Khalid University, Abha, Saudi Arabia \\ ${ }^{3}$ Department of Pathology, National Research Center, Dokki, Giza, Egypt
}

\begin{abstract}
Background: Sarcocystis fusiformis is an apicomplexan intracellular protozoan parasite that infects Indian water buffalo, Bubalus bubalis, in Egypt.

Aim of the Work: The purpose of the study was to assess the changes in the immune parameters of male Wistar rats following their oral administration with thermally treated or fresh extract of Sarcocystis.

Materials and Methods: Sarcocysts were isolated from the esophageal muscle specimens that were collected from the slaughtered Indian water buffaloes. These cysts were morphologically described by light microscopy and transmission electron microscopy. Rats (18 per group) were orally administered with; saline (control group), thermally treated cyst extract (heated group) or fresh cyst extract (fresh group). The serum levels of interleukin (IL)-1 $\beta$, IL-18, IL-15, tumor necrosis factor (TNF)- $\alpha$, IL-12, IL-10, and IL-13 were measured on days 7, 14, and 28 post-administration. Cells positive for CD4, CD8,

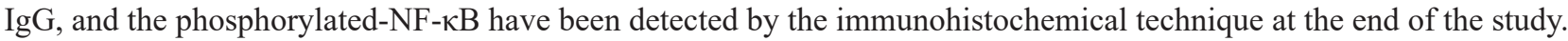

Results: In both thymus and spleen, the area\%, as well as the number of CD4+ and CD8+ T cells in response to the fresh extract were significantly increased compared to the control group. On day 28 , the fresh extract induced a significant increase in the levels of IL-1 $\beta$, IL-18, IL-15, IL-12, IL-10, and IL-13 while thermally treated extract was significantly elicited higher levels of IL-15, IL-12, and IL-13 in comparison to the control group. The number of positive splenocytes for phosphorylated$\mathrm{NF}-\kappa \mathrm{B}$ was significantly higher in the fresh group than in the heated or control group. In response to fresh extract, the number of IgG+ cells was markedly increased in the follicular zone of the lymph node in comparison with controls.

Conclusion: The state at which the parasite extract was administered (fresh or thermally treated cysts) has an inherent influence on immune responses, both innate and adaptive.
\end{abstract}

Received: 18 January 2020, Accepted: 07 March 2020

Key Words: Cytokines, immune responses, lymphoid tissues, phosphorylated NF-kB, sarcocystis fusiformis.

Corresponding Author: Abeer M. Badr, PhD, Department of Zoology, Faculty of Science, Cairo University, Cairo 12613, Egypt, Tel.: +20 1099588150, E-mail: abeerbadr@cu.edu.eg

ISSN: 1110-0559, Vol. 43, No.4

\section{INTRODUCTION}

Sarcocystis (S.) fusiform is a zoonotic parasite, belongs to the protozoan phylum Apicomplexa of a heteroxenous life cycle. The life cycle of this parasite is to be completed by both final and intermediate hosts. Both definitive and intermediate hosts are required to complete the life cycle of this parasite. Asexual reproduction inside the intermediate hosts like herbivores and omnivorous animals, as well as birds ${ }^{[1,2]}$ is alternated with the sexual phase inside the final hosts of carnivore animals such as dogs, cats, wolves and humans ${ }^{[3,4]}$. The sporocysts that infected the intermediate host, are ruptured and the released sporozoites migrate to the mucosal layer of the intestine, forming the first and the second generations of merogony. Ultimately, the merozoites penetrate the cardiac and smooth muscle cells, and develop into sarcocysts that contain bradyzoites and represent the infection phase for the definitive host ${ }^{[5]}$.
The mucosal layer of the intestine acts as one of the immunological barriers to various pathogens and microorganisms ${ }^{[6]}$. Protozoan parasites that proceed to the mucosal layer of the gut can exhibit barrier function loss and induction of inflammatory disorders that are characterized by generation of inflammatory cytokines such as TNF- $\alpha$, IFN- $\gamma$, IL- 1 , and IL- $8^{[6]}$.

Eventually, the pattern recognition receptors (PRRs) are used to mediate the identification of a pattern-associated molecular proteins (PAMPs). Progenitors of the lymphoid lineage give rise to a class of innate lymphoid cells (ILCs) that carry receptors for antigens that are not specific as those of ordinary B and T cells. ILCs are divided into ILC1, ILC2, and ILC3 depending on the secretion of comparable cytokine profiles $^{[7]}$ like CD4+ T helper (Th) cell subsets including cells of Th1, Th2, and Th17 ${ }^{[8,9]}$. Activation of ILCs by microbial products, stress signals, and cytokines from the neighboring 
cells leads to the production of effector cells with an intense immune response to various helminths, pathogens, and allergens ${ }^{[8]}$. Cytokines that produced by ILCs in response to the affected tissues, can define the shape of the adaptive arm of immunity ${ }^{[7]}$.

During infection, protozoan products can stimulate immune responses and produce effector innate immune cells ${ }^{[8]}$. There are several transcriptional factors, such as NF-kappa B (NF-kB), which promotes the expression of encoding genes for numerous proinflammatory cytokines ${ }^{[10]}$. Within infection by a parasitic protozoan, epithelial cells contained in the intestine identify PAMPs through PRRs ${ }^{[11]}$ such as Toll-like receptor (TLR)-2 and TLR-4 ${ }^{[12]}$ which, in turn, activates NF- $\kappa B$ that induces the development of proinflammatory cytokines (IL-6, IL-8, IL-12, IFN- $\beta$, IL-1 $\beta$, and TNF- $\alpha)^{[13,14]}$, leading to Th1 response of being activated $^{[15]}$.

In the present study, morphological description of $\mathrm{S}$. fusiformis that were isolated from the water buffalo, Bubalus bubalis, was carried out by light and transmission electron microscopy. Moreover, cytokines signature was assessed as markers of immune activation in male Wistar rats after repeated oral administration of freshly or thermally treated sarcocysts. Alterations in the T cell subpopulations, including $\mathrm{CD} 4+$ and $\mathrm{CD} 8+$, in addition to the phosphorylated (phospho)-NF- $\mathrm{kBp} 65$ and $\mathrm{IgG}$ positivity in the primary and secondary lymphoid organs were investigated.

\section{MATERIALS AND METHODS}

\section{Parasite Isolation and Morphological Study}

Fresh muscle specimens of the esophagus were collected from water buffaloes, Bubalus bublais (Family: Bovidae) that were slaughtered at El Basatin abattoir during July 2015 through June 2016, were transported in boxes of ice to Parasitology laboratory, Faculty of Science, Cairo University till examined.

\subsection{Light Microscopy}

Detection of sarcocysts was done by visual investigation of the muscular tissues. The identified cysts have been dissected out and their measure was calculated by a clear plastic ruler. Samples were then divided into about $1 \mathrm{~cm}^{3}$ thick specimens, fixed by neutral buffered formalin $10 \%$ and processed for histopathological technique according to Bancroft and Steven ${ }^{[16]}$ through dehydration in graded ethanol, incorporated in paraffin wax, then cut into at $5 \mu \mathrm{m}$ in thickness followed by hematoxylin and eosin (H\&E) staining. Sections were evaluated with Zeiss photomicroscope (135 Axiovert) equipped by Canon digital camera.

\subsection{Transmission Electron Microscopy}

For ultrastructural studies, specimens of sarcocysts were fixed in $2.5 \%$ cold glutaraldehyde and processed for transmission electron microscopy (TEM) according Dubey et $a{ }^{\left[{ }^{[17]}\right.}$. The sarcocysts were treated with an aqueous toluidine blue in $1 \mu \mathrm{m}$-thick resin sections. The ultra-thin sections were prepared from the sarcocysts at a thickness between 60 and 80 Ao by diamond knife, collected on copper grids, stained with uranyl acetate followed by lead citrate. The ultra-sections were examined by with Jeol 1220 TEM.

\subsection{Animals}

Male Wistar rats were supplied by Theodore Bilharz Research Institute, Giza, Egypt, weighing $150 \pm 10$ g. Rats were housed in polyacrylic cages (six animals per cage) at a temperature of $22 \pm 2{ }^{\circ} \mathrm{C}, 55 \pm 5 \%$ humidity, $12 / 12 \mathrm{~h}$ dark/ light cycle, and fed on standard food as well as tape water ad libitum. The rats were free of parasites as diagnosed by direct moist saline smear and flotation process for multiple times in stool samples ${ }^{[18]}$. All testing procedures that were performed on animals were approved by Cairo University Institutional Animal Care and Use Committee (Egypt) with permit number: CUFS/F/Immu/42/15 according to the World Organization for Animal Health (OIE) and Guide for the Care and Use of Laboratory Animals 8th Edition 2011.

\subsection{Preparation of Sarcocysts Extract}

After isolation of sarcocysts from various tissues, they were washed thrice to remove attached bovine tissue, then manually homogenized in radioimmunoprecipitation assay (RIPA) lysis buffer (Abcam, USA) by pestle homogenizer, placing it in ice to avoid heating. Ten to twenty microliters of a protease inhibitors mixture were added to the cyst homogenate. The homogenate suspension was centrifuged at $10,000 \mathrm{rpm}$ at $4^{\circ} \mathrm{C}$ by cooling centrifuge for $20 \mathrm{~min}$. The supernatant was then gathered in a sterile tube. The Bradford method was applied to estimate the protein content of the crude cyst extract ${ }^{[19]}$. The samples were preserved at $-20^{\circ} \mathrm{C}$ until use.

\subsection{Study Design}

Fifty-four Wistar rats were divided into three groups (18 per each group); Group I (control): orally administered with phosphate buffered saline (PBS), Group II (heated): orally administered with $400 \mu \mathrm{l}$ of thermally treated sarcocysts $\left(60^{\circ} \mathrm{C}\right)$ suspension for $20 \mathrm{~min}$, Group III (fresh): orally administered with $400 \mu \mathrm{l}$ of fresh sarcocysts suspension. Either rats of fresh or thermally treated group were orally administered on day 0 , followed by second and third doses on days 7 and 14, respectively. Six animals were euthanized on days 7, 14 and 28 from each group.

\subsection{Euthanization and Samples Collection}

Samples of blood were collected from rat groups under anesthesia with sodium pentobarbital $(50 \mathrm{mg} / \mathrm{kg})$ and death was confirmed by cutting major blood vessel. Blood was gathered in tubes and centrifuged to isolate serum and stored at $-80 \mathrm{oC}$ until further use. Animals were dissected to collect spleen, thymus and lymph nodes, followed by preservation in $10 \%$ neutral buffer formalin solution for histological study.

\subsection{Cytokines Assays}

The levels of TNF- $\alpha$, IL-10 and IL-1 $\beta$ (eBioscience, USA) as well as IL-12, IL-13, IL-15, and IL-18 (CloudClone Corp, CCC, USA) were estimated using enzyme- 
linked immunosorbent assay (ELISA) kits according to manufacturer's instructions. All coated wells for all determined cytokines were incubated with diluted serum samples as well as two-fold serial dilutions of each standard cytokine. After that, anti-rat antibodies (biotinylated conjugate) were added into each well and incubated for 2 $\mathrm{h}$ at room temperature (RT). After period of incubation and washing, streptavidin-HRP (diluted color development enzyme) was added for $1 \mathrm{~h}$ at RT. Then, unbound streptavidin was removed by washing followed by tetramethylbenzidine (TMB) substrate incubation in the dark as a color developing agent within $30 \mathrm{~min}$. At the end, the reaction of the enzyme was terminated when a stop solution was added. The formed colored product is proportional to amount of serum cytokine. The absorbance was measured at $450 \mathrm{~nm}$ by ELISA reader (Das, Italy). The cytokine concentration was calculated from the standard curve and expressed as $\mathrm{pg} / \mathrm{ml}$.

\subsection{Immunohistochemistry}

Paraffin blocks were sectioned and transferred to glass microscope slides pre-coated with poly-L-lysine. Slides were dewaxed and rehydrated. Endogenous peroxidase was blocked with $0.3 \% \mathrm{H}_{2} \mathrm{O}_{2}$ in PBS and nonspecific binding sites were blocked with $1.5 \%$ normal rabbit serum in PBS. Sections were incubated with primary mouse anti-rat CD4 (Nova Biologics, INC., USA), mouse anti-rat CD8 (BioRad, USA), rabbit polyclonal anti-mouse phospho-RELA (S536) antibody (phospho-NF-kB-p65) (Cusabio, Bioteck $\mathrm{Co}, \mathrm{Ltd}$ ) or goat anti-rat IgG (ProSci, incorporated, USA) monoclonal antibodies diluted in PBS containing 2\% fetal bovine serum in a humid chamber overnight at $4^{\circ} \mathrm{C}$. The sections were washed in PBS and incubated with a secondary biotinylated goat anti-mouse IgG (MyBioSource, USA), goat anti-rabbit IgG (Abcam, USA), or biotinylated donkey anti-goat IgG (Bio-Rad, USA) antibodies for $45 \mathrm{~min}$. The slides were subsequently stained for three minutes with a 3-minute diaminobenzidine solution and counterstained in Mayer's hematoxylin solution (Merck, Germany). Slides were evaluated and the positivity for the all immunological markers was identified by a digital camera (Microscope Digital Camera DP70, Tokyo).

\subsection{Immunomorphometric Analysis}

The morphometric examination was achieved by using Leica Qwin 500 Image Analyzer (LEICA Imaging Systems Ltd, Cambridge, England,) that consisted of Leica DM-LB microscope, supported by a JVC color video camera attached to a computer system Leica Q 500 IW.

\subsection{Statistical Analysis}

The effect of the treatment state (fresh or thermally treated) and experimental timepoints (7,14 and 28 days) on the levels of cytokines was estimated by two-ways analysis of variance (ANOVA). Also, the effect of treatment state (fresh or heated) on the immunostained parameters at end of the study in varous lymphoid tissues understudy was assessed using one-way ANOVA. Duncan and least significant difference (LSD) tests were utilized to consider the similarities among all the experimental groups as wellas significant differences between the experimental intervals. Data were presented as a mean \pm standard error of mean (SEM). Pearson's correlation coefficient was applied to correlate any change in the level of cytokines and the experimental peroids. Significance level was $P<0.05$. The raw data have been analyzed by IBM, SPSS Statistics (Statistical Package for the Social Sciences, SPSS version 22).

\section{RESULTS}

\subsection{Parasitological Study}

Ovoid cysts that were observed macroscopically in host esophagus muscles measured 142-210 $\mu \mathrm{m}$ long and 35-110 $\mu \mathrm{m}$ wide (Figures $1 \mathrm{~A}$ and B). Examination of histopathological sections through infected muscles by light microscopy has shown that each sarcocyst within parasitophorous vacuole was bordered by a cyst wall with underneath ground substance while the cyst cavity was divided into compartments separated by septa (Figure 1C). Ultra-thin sections from sarcocysts examined by TEM revealed that all the isolated sarcocysts have a distinct primary cyst wall (Figure 1D) with numerous irregular cauliflower projections filled with internal fibrillary elements. Furthermore, knoblike electron dense elevations were found attached to the projections. The cyst cavity of sarcocysts was occupied by globular metrocytes, and banana-like merozoites (Figure 1E). Metrocytes were differentiated from merozoites by their oval to globular form, absence of conoids and the less osmiophilic cytoplasm. Merozoites were banana-shaped with anterior polar ring, rhopteries, micronemes, conoids which were as a hollow cone or a hump structure under the anterior polar ring, (Figure 1E).

\subsection{Cytokine Profile}

\section{$I L-1 \beta$}

The level of IL-1 $\beta$ was significantly $(P<0.001)$ affected by the state of the inoculated $\mathrm{S}$. fusiformis extract (heated or fresh) as well as the experimental periods. Fresh extract of sarcocysts provoked significantly $(P<0.05)$ higher levels of IL-1 $\beta$ compared to control rats at all experimental time periods. However, thermally treated form did not provoke any significant differences. In fresh group, orally administered rats revealed significant $(P<0.05)$ higher levels of IL-1 $\beta$ at day 28 than those at day 14 (Figure 2A).

\section{IL-18}

The level of IL-18 was significantly affected by the state of the sarcosysts extract as well as experimental periods $(P<0.001)$. Administration of extracts from fresh cysts showed significantly $(P<0.05)$ higher levels of IL18 compared to control rats while heated extracts of cysts showed non-significant changes during all experimental time points. Administration with fresh extract of sarcosyts induced significant $(P<0.05)$ elevation in the levels of IL18 at days 14 and 28 compared to days 7 and 14, respectively (Figure 2B). 


\section{IL-15}

The levels of IL-15 were significantly $(P<0.001)$ affected by the state of parasite inoculated as well as experimental periods $(P<0.01)$. Both thermally treated and fresh cyst extract induced significant $(P<0.05)$ higher levels of IL-15 compared to control rats at all investigated time points. Oral administration with fresh extract of sarcosyts induced significant $(P<0.05)$ elevation in the levels of IL18 at days 14 and 28 compared to days 7 and 14, respectively (Figure 2C).

\section{$T N F-\alpha$}

The level of TNF- $\alpha$ was significantly $(P<0.001)$ affected by the state of the sacosysts extract but was insignificantly affected by the experimental periods. Administration with fresh sarcocysts extract induced marked higher levels $(P<0.05)$ of TNF- $\alpha$ compared to control rats at all experimental time points. In contrast, heated form of inoculated cyst antigen has no significant impact on the levels of TNF- $\alpha$ (Figure 2D).

\section{IL-12}

The level of IL-12 was significantly $(P<0.001)$ affected by the state of the $\mathrm{S}$. fusiformis extract as well as experimental periods. In rat group inoculated fresh cyst extract, the level of IL-12 were significantly $(P<0.05)$ higher than those control rats starting from day14 up to day 28. In contrast, heated form of the antigen extract failed to promote significant levels of IL-12 compared to control group. Oral administration with fresh extract of sarcosysts induced elevation in the levels of IL-12 at days14 and 28 compared to days 7 and 14, respectively (Figure 2E).

\section{IL-10}

The level of IL-10 was significantly affected by the state of the parasite extracts inoculated as well as experimental periods $(P<0.001)$. Level of IL-10 was increased significantly $(P<0.05)$ after treatment with fresh sarcocysts extract compared to control rats. Significant $(P<0.05)$ higher levels of IL-10 at days 14 and 28 than day 7 were evident in fresh group (Figure 2F).

\section{IL-13}

The level of IL-13 was significantly $(P<0.001)$ affected by the state of the sarcocysts inoculated as well as experimental periods. Sarcosysts extract inoculation exhibited a significant elevation in the levels of IL-13 compared to control rats during all experimental periods. Orally inoculated rats with either heated or fresh cyst extracts showed significant higher levels of IL-13 at day 14 compared to day7 (Figure 2G).

\subsection{Correlation Between the Levels of Cytokines and the Experimental Periods}

All measured cytokines showed a positive correlation with time after administration with fresh antigen extract along the experimental time points, except IL-15 that showed a reverse correlation. Thermally treated state of the antigen extract demonstrated a positive correlation with the time points for the levels of IL-1 $\beta$, IL-18, IL-10 and IL-13 while an inverse correlation was observed for the levels of TNF- $\alpha$, IL-12, and IL-15 (Table1).

\subsection{Immunohistochemical Studies}

\subsubsection{Expression of CD4+ and CD8+ T Cells in Thymus}

The expression of $\mathrm{CD} 4+$ and $\mathrm{CD} 8+$ positivity was demonstrated in the thymus sections for all studied rat groups (Figure 3). The area percentage (\%) of CD4+ and CD8+ T positive cells in the medulla of thymus was significantly increased $(P<0.05)$ in rats orally administered with the fresh extract. The total number of positive CD4+ and CD $8+$ T cells in thymus showed a significant increase in rats orally treated with fresh extract compared to controls (Table 2).

\subsubsection{Expression of CD4+, CD8+, and phospho-NF- $\boldsymbol{\kappa}$ in Spleen}

The positivity of CD4, CD8 and phospho-NF-кB was demonstrated in the spleen sections for all studied rat groups (Figure 4). The area $\%$ positivity for $\mathrm{CD} 4+$ or $\mathrm{CD} 8+\mathrm{T}$ cells was significantly increased in area of follicles and marginal zone of rats administered with fresh antigen compared to the control rats, while response to heated antigen showed some differences but were not statistically significant. The area $\%$ of positive phospho-NF- $\kappa$ Bp65 was declined in case of heated group while fresh group showed a significant increase in areas including follicular and marginal zone. In fresh group, the immune-stained areas of the spleen compartments showed significantly higher number of positive CD4, CD8, or phospho-NF-kBp65 cells in both areas of follicular and marginal zone than in control group (Table 3 ).

\subsubsection{Expression of IgG + Cells in Lymph Node Tissue}

The expression of IgG positivity was demonstrated in the lymph node sections for all studied rat groups (Figure 5). By immunohistochemical analysis, a significant higher area $\%$ positivity of $\operatorname{IgG}$ was recorded in the medullary sinus of rats treated with heated antigen than those in control rats. The number of $\mathrm{IgG}+$ cells was significantly increased in rats treated with thermally extracts of parasite sarcocysts compared to control rats in both follicular area and medullary sinus of the lymph node (Table 4). 

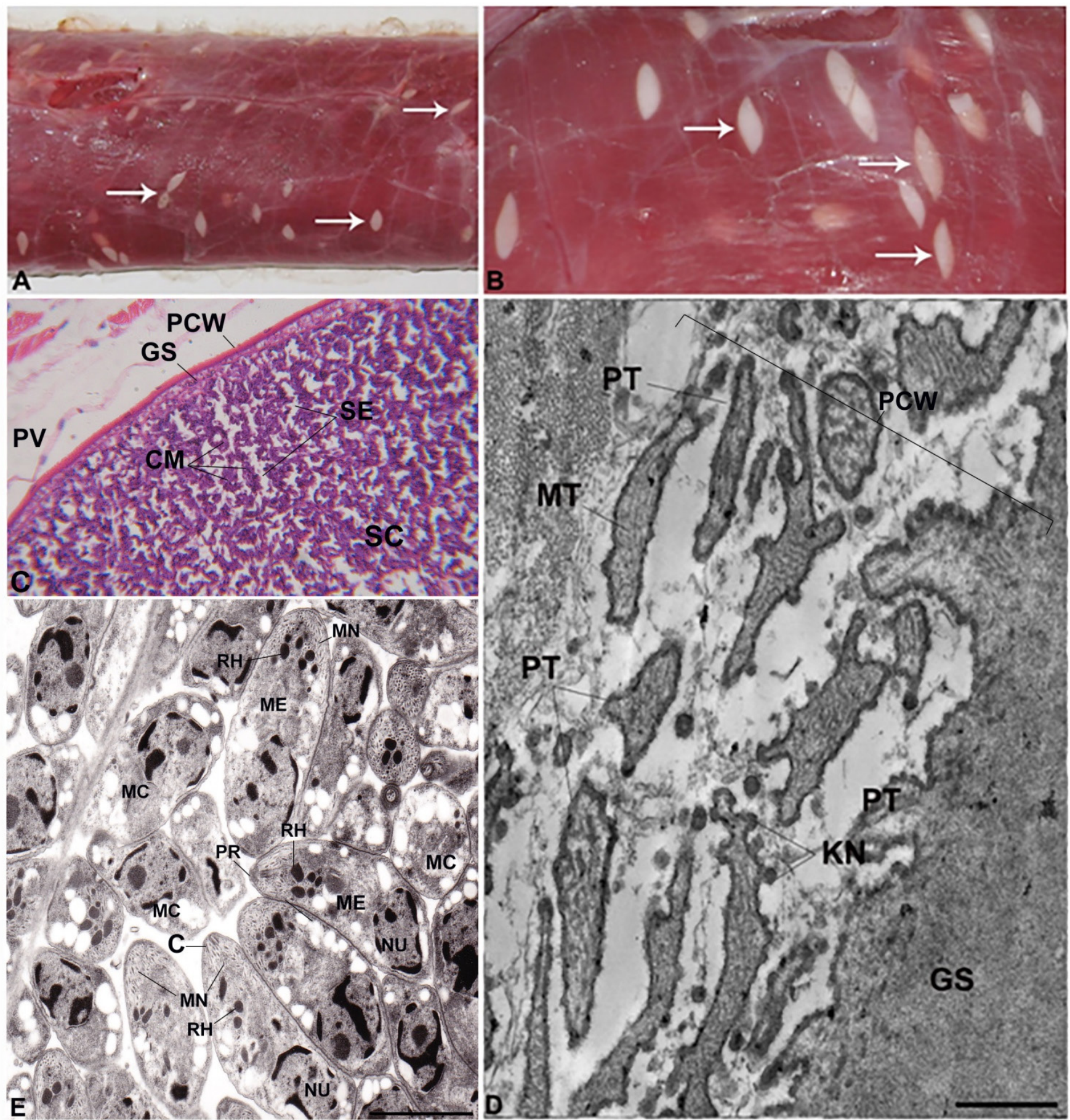

Fig. 1 (A, B): Photographs showing part of a buffalo oesophagus heavily infected with sarcocysts (arrows) of Sarcocystis fusiformis. The infection appeared as macroscopic spindle shaped and whitish sarcocysts embedded in the host muscles. C: Photomicrographs showing a histological section stained with H\&E through host esophagus infected with sarcocysts (SC) within parasitophorous vacuole (PV), the cyst is bordered by a primary cyst wall (PCW) underlined by a layer of ground substance (GS) extended into the interior of the cyst as septa (SE) dividing it into compartments (CM), $\mathrm{x}$ 140. D, E: Transmission electron micrographs of ultrathin section through a parasite sarcocyst showing the ultrastructural characteristics of: D: The primary cyst wall (PCW) underlined by a layer of thick ground substance (GS). The primary cyst wall has cauliflower-like protrusions (PT) of variable size and shape with knob (KB) like structures surrounding the outer layer of each protrusion, MT microtubules. E: Part of the interior of a sarcocyst filled with metrocytes (MC) and merozoites (ME). Merozoites This motile infective stage retained most of the apical complex structural characteristics such as conoid (C), micronemes (MN), rhoptries (RH), and polar ring (PR). NU for Nucleus. Scale bars $500 \mathrm{~nm}$. 

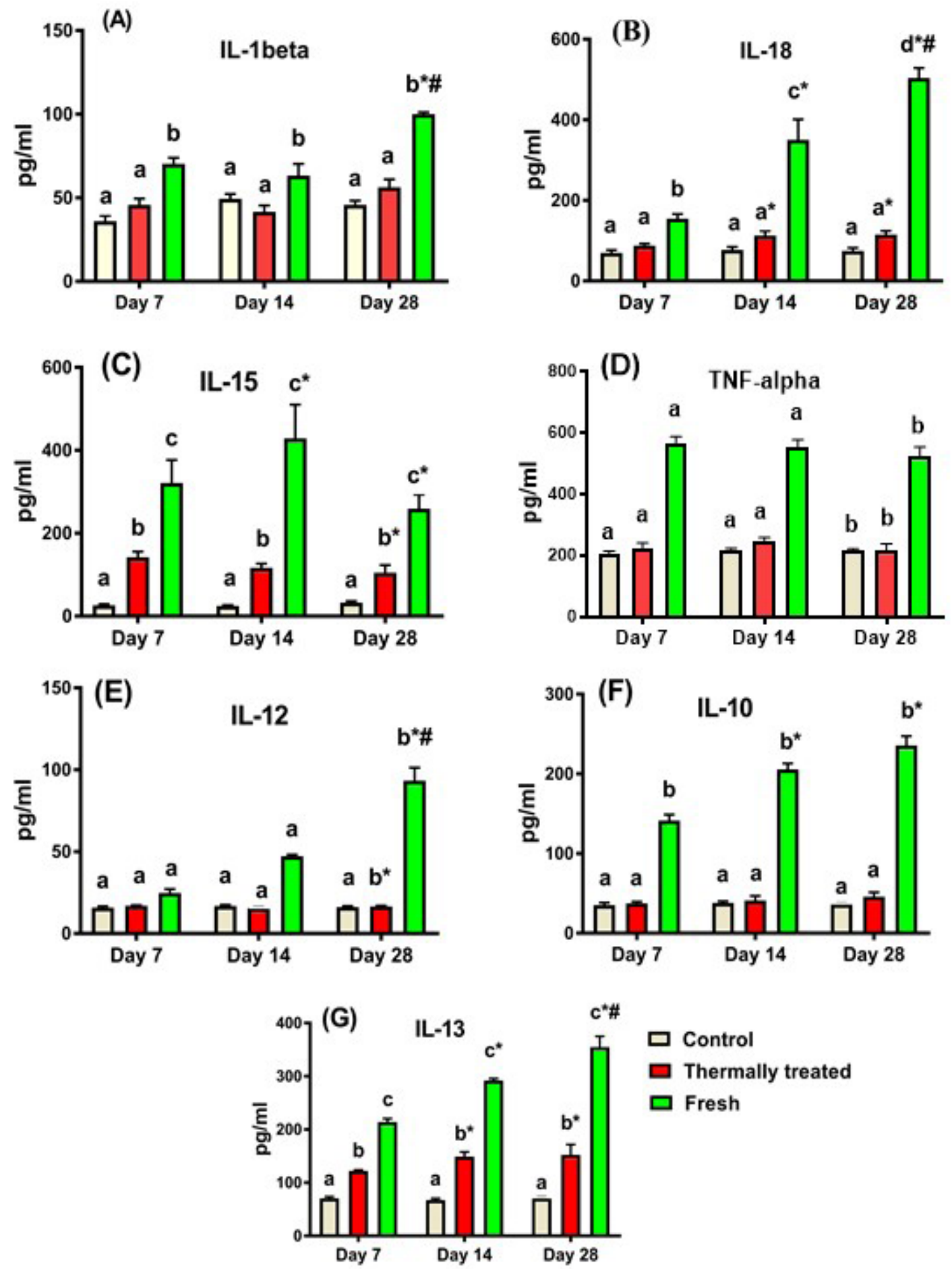

Fig. 2: Cytokines levels associated with innate and adaptive immune responses. Levels (pg/ml) of (A) IL-1 $\beta$, (B) IL-18, (C) IL-15, (D) TNF- $\alpha$, (E) IL-12, (F) IL-10, and (G) IL-13 in serum of rats treated with; PBS (control group), sarcocysts antigen either thermally treated (heated group) or fresh (fresh group). Data are expressed as mean of six rat $\mathrm{s} \pm$ standard error of the mean (SEM). In the same day, mean values marked with similar superscript letters are insignificantly differed $(\mathrm{P}>0.05)$, whereas those with different ones are significantly differed $(\mathrm{P}<0.05)$. In the same group, the mean values marked with *, \#: significant differences $(\mathrm{P}<0.05)$ as compared to the day7 and day 14 , respectively. Scale bars $=50 \mu \mathrm{m}$. 

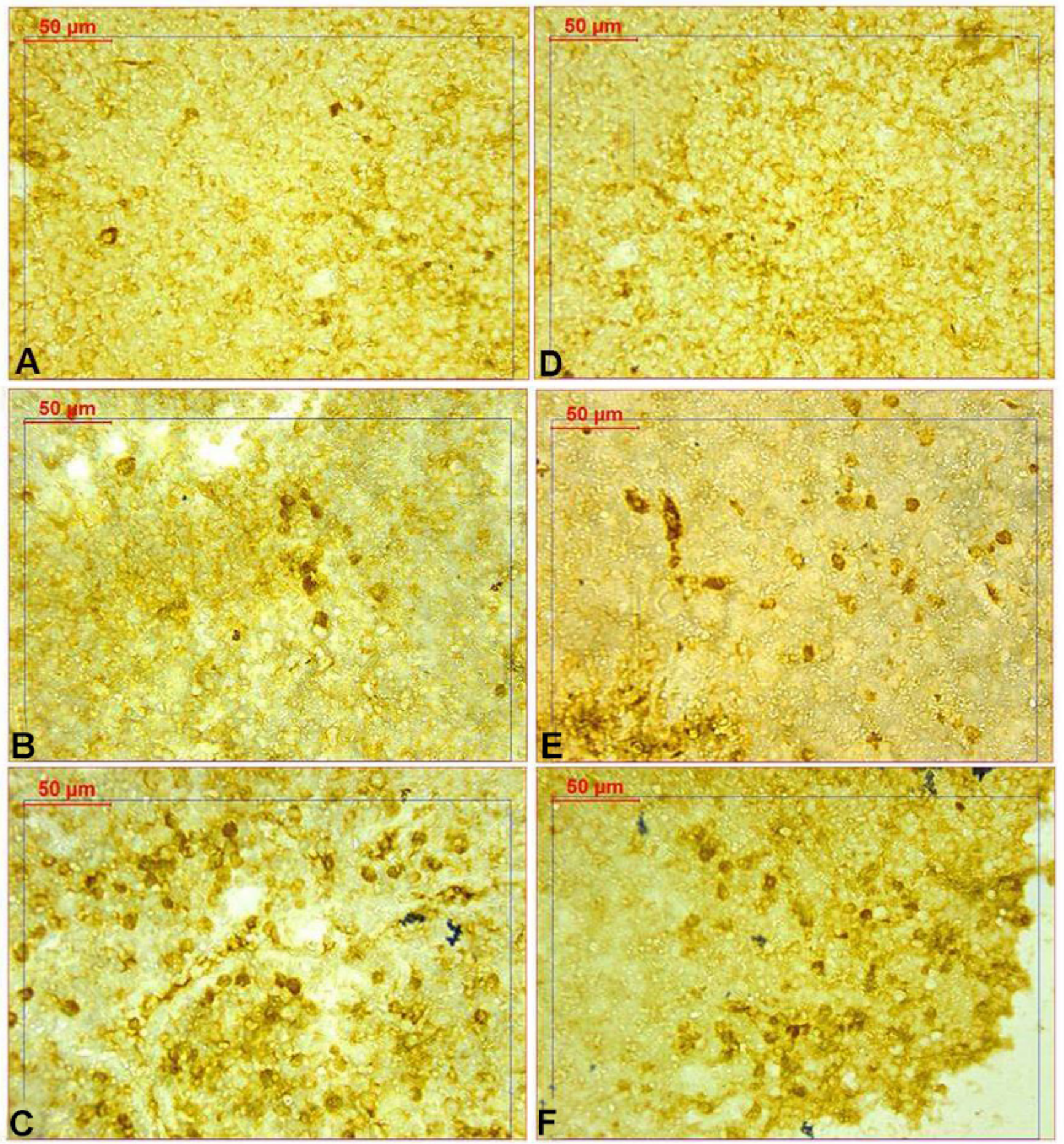

Fig. 3: Representative photomicrographs for thymus sections immunostained for positive CD4+ and CD8+ T cells that appeared as brown color with varies degrees. (A) CD4+ jn control, (B) CD4+ in heated group administered with thermally treated sarcocysts extract, (C) CD4+ in fresh group administered with fresh sarcocysts extract; (D) CD8+ in control group, (E) CD8+ in heated group administered with thermally treated sarcocysts extract. (F) CD8+ in fresh group administered with fresh sarcocystes extract. Scale bars $=50 \mu \mathrm{m}$. 


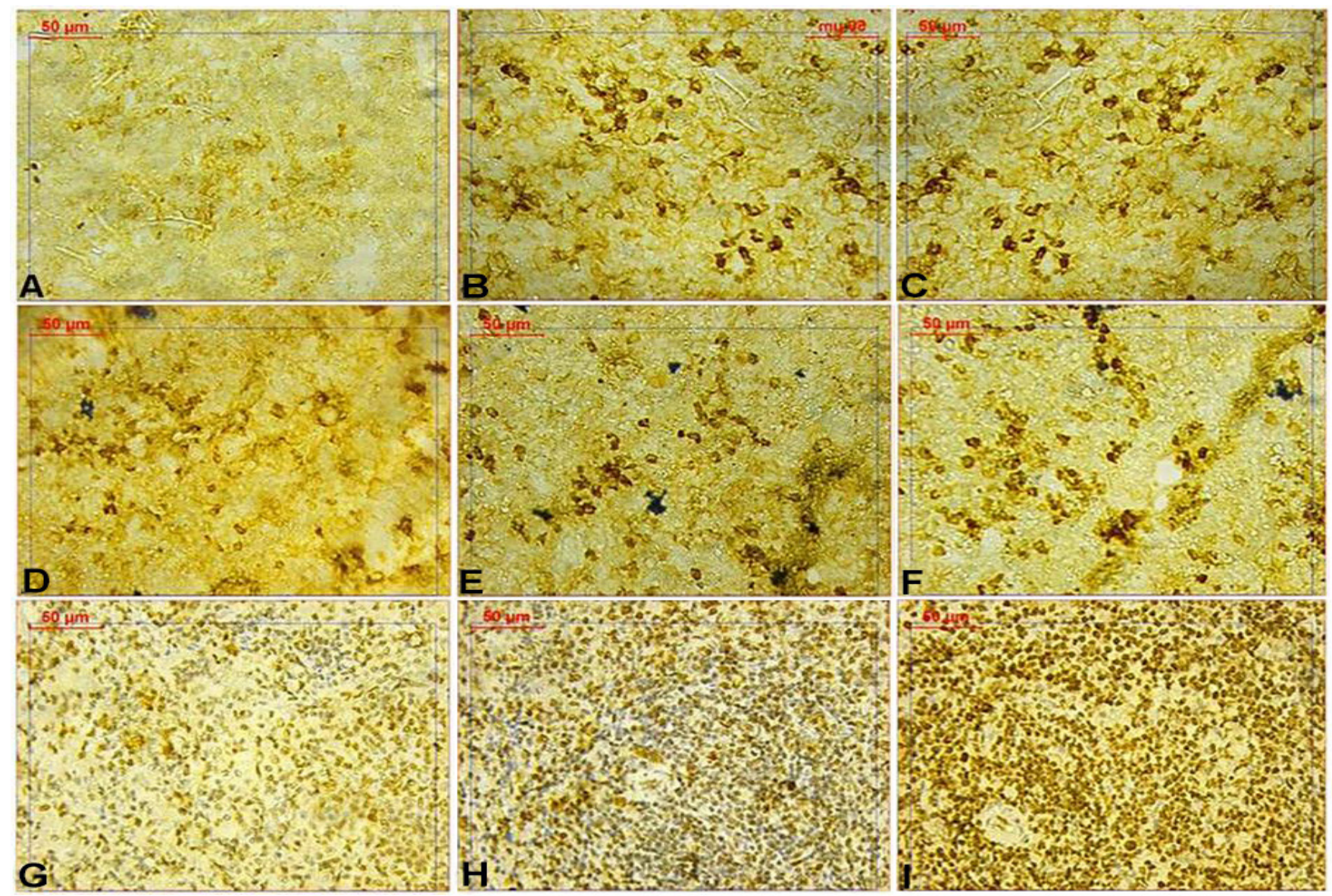

Fig. 4: Representative photomicrographs of spleen sections immunostained for CD4+ and CD8+ T cells as well as phospho-NF- $\kappa \mathrm{B}$ positive inflammatory cells appeared as brown color with varies degrees. (A) CD4+ in control, , (B) CD4+ in heated group administered with thermally treated sarcocysts extract, (C) CD4+ in fresh group administered with fresh sarcocysts extract; (D) CD8+ in control, (E) CD8+ in heated group administered with thermally treated sarcocysts extract, (F) CD8+ in fresh group administered with fresh sarcocysts extract; (G) phospho-NF- $\kappa$ B-p65 in control group, (H) phospho-NF- $\kappa$ B-p65 in heated group administered with thermally treated sarcocysts extract. (I) phospho-NF- $\mathrm{KB}-\mathrm{p} 65$ in fresh group administered with fresh sarcocysts extract. Scale bars $=50 \mu \mathrm{m}$.
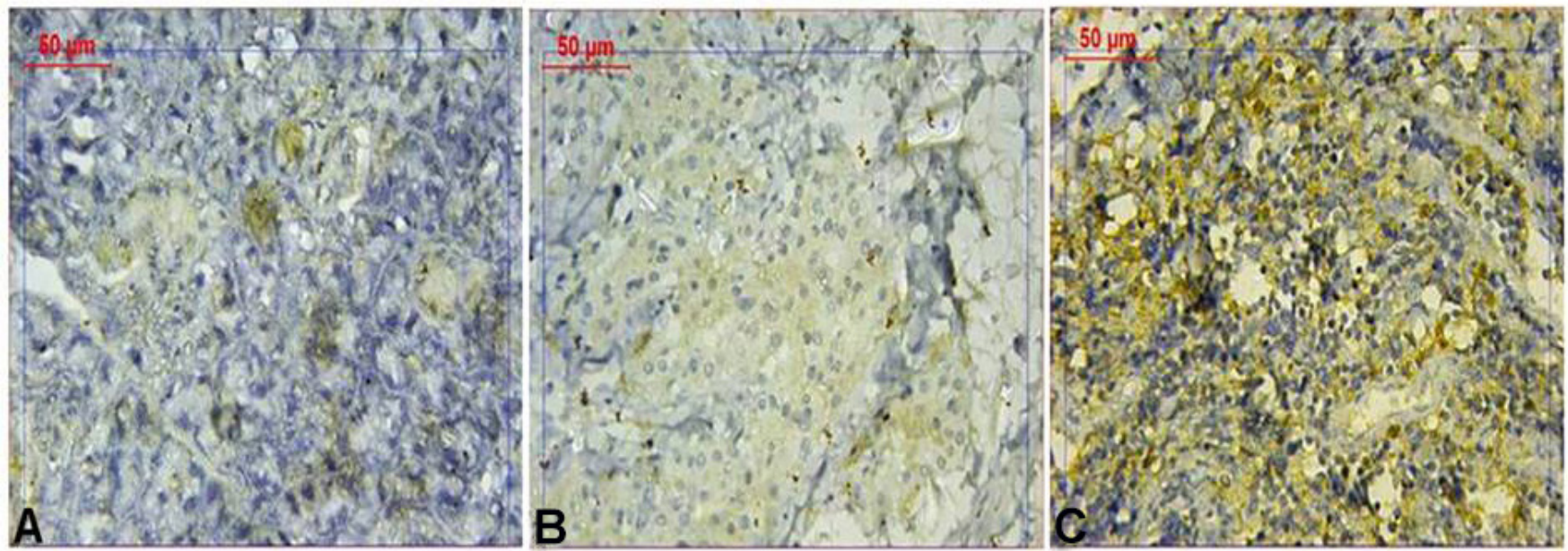

Fig. 5: Representative photomicrographs of lymph node sections immunostained for IgG+ appeared as brown color with varies degrees. (A) IgG+ in sections from control group, (B) $\mathrm{IgG}+$ in sections from heated group administered with thermally treated sarcocysts extract, $(\mathrm{C}) \mathrm{IgG}+$ in sections from fresh group administered with fresh sarcocysts extract. Scale bars $=50 \mu \mathrm{m}$. 
Table 1: Correlation between the levels of the cytokines and the experimental periods in the rat groups administered with fresh and thermally treated (heated) extract of S. fusiform cysts

\begin{tabular}{|c|c|c|c|c|}
\hline \multirow{3}{*}{ Cytokines } & \multicolumn{4}{|c|}{ Experimental groups } \\
\hline & \multirow{2}{*}{$\frac{\text { Heated }}{\mathrm{r}}$} & \multirow{2}{*}{$\begin{array}{c}\text { Fresh } \\
\mathrm{r}\end{array}$} & Heated & Fresh \\
\hline & & & \multicolumn{2}{|c|}{ Regression analysis } \\
\hline IL-1 $\beta$ & 0.817 & 0.869 & $y=0.5741 x+38.54$ & $y=1.586 x+51.955$ \\
\hline TNF- $\alpha$ & -0.475 & 0.999 & $y=240.66 e^{-0.0033 x}$ & $y=1.8783 x+578.31$ \\
\hline IL-12 & -0.074 & 0.999 & $y=17.076 x^{-0.018}$ & $y=3.2699 x+1.705$ \\
\hline IL-18 & 0.804 & 0.966 & $\mathrm{y}=62.008 \mathrm{x}^{0.1976}$ & $\mathrm{y}=252.01 \ln (\mathrm{x})-328.88$ \\
\hline IL-15 & -0.923 & -0.532 & $y=216.28 x^{-0.223}$ & $\mathrm{y}=413.11 \mathrm{e}^{-0.014 x}$ \\
\hline IL-10 & 0.986 & 0.922 & $\mathrm{y}=29.384 \mathrm{x}^{0.1279}$ & $\mathrm{y}=68.001 \ln (\mathrm{x})+14.827$ \\
\hline IL-13 & 0.818 & 0.968 & $y=92.348 x^{0.1593}$ & $\mathrm{y}=101.51 \ln (\mathrm{x})+19.088$ \\
\hline
\end{tabular}

r: correlation coefficient

Table 2: Area percentage and the number of CD4 and CD8 positive T cells in different parts of the immunohistochemically stained thymus sections in the control as well as the orally administered rats with freshly or thermally treated (heated) extract of S. fusiform cysts

\begin{tabular}{|c|c|c|c|c|c|c|c|}
\hline \multirow{3}{*}{$\begin{array}{l}\text { Parameters } \\
\text { Area\% of CD4+ (cortex) }\end{array}$} & \multicolumn{5}{|c|}{ Experimental groups } & \multirow{2}{*}{\multicolumn{2}{|c|}{ One-way* ANOVA }} \\
\hline & \multirow{2}{*}{$\frac{\text { Control }}{0.428 \pm 0.12^{\mathrm{a}}}$} & \multicolumn{2}{|c|}{ Heated } & \multicolumn{2}{|c|}{ Fresh } & & \\
\hline & & $0.490 \pm 0.07^{\mathrm{ab}}$ & $14.48 \%$ & $0.658 \pm 0.07^{\mathrm{b}}$ & $53.73 \%$ & $\mathrm{~F}_{2,24}=3.69$ & $P<0.05$ \\
\hline Area $\%$ of CD $4+$ (medulla) & $0.512 \pm 0.05^{\mathrm{a}}$ & $0.556 \pm 0.24^{\mathrm{a}}$ & $8.59 \%$ & $0.886 \pm 0.18^{b}$ & $73.04 \%$ & $\mathrm{~F}_{2,24}=20.71$ & $P<0.001$ \\
\hline Number of CD4+ (thymus) & $18.80 \pm 1.65^{\mathrm{a}}$ & $28.80 \pm 17.8^{\mathrm{ab}}$ & $53.19 \%$ & $38.20 \pm 0.07^{\mathrm{b}}$ & $103.19 \%$ & $\mathrm{~F} 2,24=2.69$ & $P \geq 0.05$ \\
\hline Area\% of CD8+ (cortex) & $0.334 \pm 0.06^{\mathrm{a}}$ & $0.610 \pm 0.30^{\mathrm{a}}$ & $82.63 \%$ & $0.490 \pm 0.07^{\mathrm{a}}$ & $46.70 \%$ & $\mathrm{~F}_{2,24}=0.859$ & $\mathrm{P} \geq 0.05$ \\
\hline Area $\%$ of CD $8+$ (medulla) & $0.422 \pm 0.05^{\mathrm{a}}$ & $0.592 \pm 0.07^{\mathrm{a}}$ & $40.28 \%$ & $1.928 \pm 0.51^{\mathrm{b}}$ & $356.8 \%$ & $\mathrm{~F}_{2,24}=7.18$ & $P<0.01$ \\
\hline Number of CD8+ (thymus) & $13.60 \pm 1.21^{\mathrm{a}}$ & $14.80 \pm 2.17^{\mathrm{a}}$ & $8.82 \%$ & $24.80 \pm 4.28^{b}$ & $82.35 \%$ & $F_{2,24}=16.77$ & $P<0.001$ \\
\hline
\end{tabular}

Data are expressed as mean of six rats \pm standard error of the mean (SEM).

In the same row, mean values marked with similar superscript letters are insignificantly differed $(P \geq 0.05)$, whereas those with different ones are significantly differed $(P<0.05)$.

*: The effect of treatment state (heated or fresh) of S. fusiform antigen on the area percentage and number of CD4+ and CD8+ cells. \%: percentage of change compared to control group

Table 3: Area percentage and the number of CD4+, CD $8+$, and phospho-NF-kB- positive cells in different parts of the immunohistochemically stained spleen sections the in control as well as orally administered rats with fresh and thermally treated (heated) extract of S. fusiform cysts

\begin{tabular}{|c|c|c|c|c|c|c|c|}
\hline \multirow{3}{*}{$\begin{array}{l}\text { Parameters } \\
\text { Area\% CD4+(Follicle })\end{array}$} & \multicolumn{5}{|c|}{ Experimental groups } & \multirow{2}{*}{\multicolumn{2}{|c|}{ One-way* ANOVA }} \\
\hline & \multirow{2}{*}{$\begin{array}{c}\text { Control } \\
0.21 \pm 0.014^{\mathrm{a}}\end{array}$} & \multicolumn{2}{|c|}{ Heated } & \multicolumn{2}{|c|}{ Fresh } & & \\
\hline & & $0.3 \pm 0.03^{\mathrm{a}}$ & $41.50 \%$ & $0.452 \pm 0.09^{b}$ & $113.20 \%$ & $\mathrm{~F}_{2,24}=10.34$ & $P<0.01$ \\
\hline Area\% CD4+ (marginal zone) & $0.21 \pm 0.008^{\mathrm{a}}$ & $0.32 \pm 0.04^{\mathrm{a}}$ & $52.38 \%$ & $0.43 \pm 0.04^{b}$ & $104.76 \%$ & $\mathrm{~F}_{2,24}=10.19$ & $P<0.01$ \\
\hline Number CD4+ cells & $8.8 \pm 1.067^{\mathrm{a}}$ & $9.29 \pm 2.96^{\mathrm{a}}$ & $5.56 \%$ & $22.30 \pm 3.82^{\mathrm{b}}$ & $153.41 \%$ & $\mathrm{~F}_{2,24}=27.10$ & $P<0.001$ \\
\hline Area\% CD8+ (Follicle) & $0.364 \pm 0.01^{\mathrm{a}}$ & $0.418 \pm 0.03^{\mathrm{a}}$ & $14.83 \%$ & $0.851 \pm 0.05^{\mathrm{b}}$ & $133.9 \%$ & $\mathrm{~F}_{2,24}=8.54$ & $P<0.01$ \\
\hline Area\% CD8+ (marginal zone) & $0.378 \pm 0.06^{\mathrm{a}}$ & $0.48 \pm 0.05^{\mathrm{a}}$ & $26.98 \%$ & $0.90 \pm 0.16^{\mathrm{b}}$ & $138.09 \%$ & $\mathrm{~F}_{2,24}=7.65$ & $P<0.01$ \\
\hline Number CD8+ cells & $19 \pm 1.581^{\mathrm{a}}$ & $21.4 \pm 2.15^{\mathrm{a}}$ & $12.63 \%$ & $32.00 \pm 2.73^{b}$ & $68.42 \%$ & $\mathrm{~F}_{2,24}=2.37$ & $P \geq 0.05$ \\
\hline Area $\%$ of p-NF-kB (follicle) & $1.63 \pm 0.747^{\mathrm{a}}$ & $0.65 \pm 0.194^{\mathrm{a}}$ & $-60.22 \%$ & $2.39 \pm 1.01^{\mathrm{b}}$ & $46.27 \%$ & $\mathrm{~F}_{2,24}=15.80$ & $P<0.01$ \\
\hline Area $\%$ of p-NF-kB (marginal zone) & $5.302 \pm 1.03^{\mathrm{a}}$ & $2.154 \pm 0.38^{\mathrm{a}}$ & $-59.37 \%$ & $7.72 \pm 1.64^{b}$ & $45.61 \%$ & $\mathrm{~F}_{2,24}=31.23$ & $P<0.001$ \\
\hline Number of p-NF-kB (follicle) & $7.4 \pm 1.83^{\mathrm{a}}$ & $17 \pm 2.28^{\mathrm{a}}$ & $-2.29 \%$ & $32 \pm 2.738^{b}$ & $83.9 \%$ & $\mathrm{~F}_{2,24}=18.75$ & $P<0.001$ \\
\hline Number of p-NF-kB (marginal zone) & $17 \pm 2.75^{\mathrm{a}}$ & $18.6 \pm 1.02^{\mathrm{a}}$ & $9.41 \%$ & $43.6 \pm 3.77^{\mathrm{b}}$ & $156.47 \%$ & $\mathrm{~F}_{2,24}=31.66$ & $P<0.001$ \\
\hline
\end{tabular}

Data are expressed as mean of six rats \pm standard error of the mean (SEM).

In the same row, mean values marked with similar superscript letters are insignificantly differed $(\mathrm{P} \geq 0.05)$, whereas those with different ones are significantly differed $(P<0.05)$.

*: The effect of treatment state (heated or fresh) of S. fusiform antigen on the area percentage and the number of CD4+, CD8+, and p-NF-kB positive cells. \%: percentage of change compared to control group. 
Table 4: Area percentage and the number of IgG positive cells in different parts of immunohistochemically stained lymph node in the control as well as orally treated rats with sarcocysts of S. fusiformis (heated or fresh) at the end of the study

\begin{tabular}{|c|c|c|c|c|c|c|c|}
\hline \multirow{3}{*}{$\begin{array}{l}\text { Parameters } \\
\text { Area } \% \text { of IgG+ (Medulla) }\end{array}$} & \multicolumn{5}{|c|}{ Experimental groups } & \multirow{2}{*}{\multicolumn{2}{|c|}{ One-way* ANOVA }} \\
\hline & \multirow{2}{*}{$\begin{array}{c}\text { Control } \\
0.16 \pm 0.037^{\mathrm{a}}\end{array}$} & \multicolumn{2}{|c|}{ Heated } & \multicolumn{2}{|c|}{ Fresh } & & \\
\hline & & $0.29 \pm 0.019^{\mathrm{b}}$ & $86.25 \%$ & $0.23 \pm 0.01^{\mathrm{c}}$ & $43.75 \%$ & $\mathrm{~F}_{2,24}=16.03$ & $P<0.001$ \\
\hline Area $\%$ of IgG + (Follicle $)$ & $0.15 \pm 0.03^{\mathrm{a}}$ & $0.22 \pm 0.067^{\mathrm{b}}$ & $41.77 \%$ & $0.19 \pm 0.03 \mathrm{a}^{\mathrm{b}}$ & $24.05 \%$ & $\mathrm{~F}_{2,24}=5.52$ & $P<0.01$ \\
\hline Number of IgG+ (Medulla) & $44.2 \pm 4.43^{\mathrm{a}}$ & $25.2 \pm 2.63^{\mathrm{b}}$ & $-42.98 \%$ & $15 \pm 1.64^{\mathrm{c}}$ & $-66.06 \%$ & $\mathrm{~F}_{2,24}=24.43$ & $P<0.001$ \\
\hline Number of IgG+ (Follicle) & $1.81 \pm 0.81^{\mathrm{a}}$ & $8.4 \pm 1.07^{\mathrm{b}}$ & $362.4 \%$ & $7.80 \pm 0.79^{\mathrm{c}}$ & $329.37 \%$ & $\mathrm{~F}_{2,24}=22.80$ & $P<0.001$ \\
\hline
\end{tabular}

Data are expressed as mean of six rats \pm standard error of the mean (SEM).

In the same row, mean values marked with similar superscript letters are insignificantly differed $(\mathrm{P} \geq 0.05)$, whereas those with different ones are significantly differed $(P<0.05)$.

*: The effect of treatment state (heated or fresh) of S. fusiform antigen on the area percentage and the number of IgG positive cells. \%: percentage of change compared to control group.

\section{DISCUSSION}

A wide variety of Sarcocystis mammals and avian harbor are rare in ectothermal vertebrate examples ${ }^{[20]}$. Sarcocystis ' coccidial existence has been explained by Fayer ${ }^{[21]}$ and Rommel et al. ${ }^{[22]}$. The infection profile has been seen in the current study was contributed to the conclusion that the risk of infection of these domestic animals is high as a result of their ambiguous relationship with other domestic animals in accordance with the study of Collier et al. ${ }^{[23]}$. Morphological characteristics of the primary cyst wall play an essential role in the recognition of Sarcocystis ${ }^{[24]}$. The basic structure of the cyst wall varies widely between different stages of parasite growth and it has been postulated that the fine structure of the Sarcocystis cyst wall can be used as a test for the identification of various species of this parasite ${ }^{[25]}$. Herein, the recovered sarcosysts had a thick primary wall, frequently collapsed into irregular folds with several variable size and cauliflower shape projections. In addition, densely elevations of the knob like electron were observed with projections. According to the study of Abdel-Ghaffar et al..$^{[26]}$ from buffaloes, similar results were achieved.

During protozoan infections, the immune system develops complex defending mechanisms, including innate immune responses to extracellular protozoan parasites by various immune cells such as macrophages, neutrophils and natural killer (NK) cells. In innate and adaptive immune reactions to intracellular parasites, cytokines made by activating macrograph and NK cells play a major role ${ }^{[27]}$.

IL-1 $\beta$ is a crucial example for proinflammatory cytokines. It is principally produced by NK and T cells, leads to NF- $\mathrm{KB}$ activation and upregulation of inflammatory mediators which stimulates recruitment of neutrophils and macrophages at inflammatory sites while retaining a Th1 protective response ${ }^{[28]}$. The presented data showed that the serum levels of IL-1 $\beta$ and TNF- $\alpha$ were markedly elevated in rats administered with fresh crude antigen of S. fusiform. These results are consistent with those of an earlier study that emphasize the role of both cytokines in defense against Staphylococcus aureus ${ }^{[29]}$, besides inflammasome activation against several disease models including infection with Leishmania ${ }^{[30]}$. It is documented that TNF- $\alpha$ functions on cytotoxic NK cells by activating NF- $\kappa B$ and MAP kinases ${ }^{[31]}$.
IL-1 family cytokines include IL-18 which deeply influenced the activation and differentiation of various $\mathrm{T}$ cell lineages and the NK cell stimulation, which elicits resistance against Toxoplasma infection ${ }^{[32]}$. Our observation supports this idea through increased levels of IL-18 after oral administration with fresh sarcocysts antigen extract. Its joining with IL-12 is directed to Th1 polarization ${ }^{[33]}$.

IL-15 is involved in stimulation of various cells such as, $\mathrm{B}$ cells ${ }^{[34]}$, NK cells ${ }^{[35]}$, and $\gamma \delta$ T cells. The obtained results demonstrated significant higher levels of circulating IL-15 in response to administration of fresh sarcocysts antigen. Other publications displayed the effect of rIL-15 on stimulation and proliferation of $\mathrm{CD} 8+\mathrm{T}$ cells after exposure to parasite antigen as well as CD8 $+\mathrm{T}$ cells proliferation following active parasite infection ${ }^{[36,37]}$. Moreover, IL-15- deficient mice exhibit mainly selective loss of NK cells, memory phenotype CD8 T cells, and NK cells ${ }^{[38]}$. Thus, both IL-15 and IL-18 stimulate secretion of IFN- $\gamma^{[39]}$. In response to microbial products, IL-12 can be produced in monocytes, macrophages or dendritic cells. It also has stimulatory effect on NK and T cells resulting in IFN- $\gamma$ production, both IL-12 and IFN- $\gamma$ promotes differentiation of Th Type 1 pattern ${ }^{[40,41]}$. Conversely, the delay secretion of IL-12 induces naive T cells to produce IFN- $\gamma$ in the lymph nodes ${ }^{[22]}$. Herein, during all time points of the current investigation, fresh sarcocysts antigen induced pronounced levels of IL-12 that resembles the case of Toxoplasma infection in the early stages, whereas IL-12 was secreted in response to the activation of macrophages and NK cells and the shift towards Tcell immune responses. In comparison to other studies including Toxoplasma, the differentiation of $\mathrm{T}$ cells and IFN- $\gamma$ production was observed during acute infection with Toxoplasma gondiii ${ }^{[40]}$. Additionally, high levels of IFN- $\gamma$ and TNF- $\alpha$ have been found to induce the secretion of IL-12, IL15 , and IL-1 $8^{[43]}$ that control apicomplexan infection. IL-12 and IL-18 or IL- $1 \beta^{[44]}$ induces IFN- $\gamma$ while IL-15 and IL-12 induces less IFN- $\gamma$ but more IL-10 and TNF- $\alpha^{[45]}$.

IL-13 is an important cytokine, mainly secreted by CD4+ Th2 cells, but can also be expressed by basophils, mast cells, eosinophils, invariant NK T cells ${ }^{[46]}$, and ILCs of type $2^{[47]}$. It is shown that IL-13 has an anti-inflammatory function in various in vitro and in vivo experiments. In the 
present study, IL-13 secretion was markedly detected in both thermally treated and fresh state of Sarcocystis antigen administration. It was reported that ILCs of type 2 have a role in immune protection against apicomplexan infections by inducing Th2 immune responses IL-4, IL-5, and IL-13 ${ }^{[9,48]}$. L-10 is therefore able to repress the proinflammatory cytokine expression like TNF- $\alpha$, IL-6 and IL-1 that are produced by stimulated macrophages. It has been observed that the pronounced production of IL-10 due to the fresh Sarcocystis antigen extracts administration in rats could be explained by its ability to inhibit IFN- $\gamma$ synthesis by NK and Th1 lymphocytes by downregulating of IL-12 ${ }^{[49,50]}$, avoiding these immunopathologic alterations associated with Type 1 cytokines accompanied Toxoplasma infection $^{[51]}$. In addition, protozoan parasite antigen exposure activates the host's immune reaction of type Th2, leading to the development of anti-inflammatory cytokines, such as IL-4, IL-10, IL-5 and IL-13, which attempt to alleviate the Th1-type response which haracterized by the INF- $\gamma$ release as well as upregulation of Th2 cytokine (IL-4, IL-5 and IL-13) ${ }^{[52]}$.

Innate immune response is considered as early barrier defense at mucosal areas of secondary lymphoid organs ${ }^{[9]}$. $\mathrm{CD} 4+\mathrm{T}$ cells are able to generate IFN $-\gamma$ in the Toxoplasma gondii infection and stimulating NK cells which also can generate IFN- $\gamma$. A Th1 response and the parasite destruction by reactive nitrogen is dependent on the IFN- $\gamma^{[53]}$. Thymus is a site for maturation of lymphocytes through a pathway from cortex to medulla. Noting that the cortex is especially sensitive to pathogen infection ${ }^{[54]}$. Positive selection enables the fresh, immature, short-lived, CD4+CD8+ thymocytes, which avoid programmed death, to evolve into mature, longlived, single-positive phase of CD4 or CD8 that make up 15 percent of the thymocytes that leave the organ to form most peripheral T-cell repertoire ${ }^{[55]}$.

Our data revealed an increase in the number of CD4+ and CD8+ T cells of the thymus of group. These results agreed with ${ }^{[56]}$ who also documented an increase in the thymocytes number in response to inflammation due to antigenic stimulation. In spleen, $T$ cells concentrated in $T$ cell-zone, resident in the spleen tissue or recruited from the blood to the marginal zone ${ }^{[57]}$ and B cells at the edges of these areas, as well as within the germinal centers, required for antibody responses ${ }^{[58]}$. The increased expression levels of CD4+ and CD8+ spleen cells after administration of the sarcosysts extracts in the current study is matched with the fact that CD8 $+\mathrm{T}$ cells could be the most important factor in cell-mediated immune responses towards $\mathrm{S}$. neurona infected $\mathrm{C} 57 \mathrm{BL} / 6$ mice $^{[59]}$, in addition, the proportion of both blood CD8+ and spleen lymphocytes on 14 day ${ }^{[60]}$. In addition, a high number of CD8+ $\mathrm{T}$ cells identify the susceptibility of mice chronically infected with Trichuris muris $^{[61]}$. Certain research findings have shown that CD8+ T and IFN $-\gamma$ generation by $\mathrm{CD} 4+\mathrm{T}$ cells defend against chronic infection with Toxoplasma as well as the threat infections in previously vaccinated mice ${ }^{[62]}$, the prepared lysate solution of bradyzoites belong to sarcocysts has an effect similar to acute phases of sarcocystosis in calves ${ }^{[63]}$. Subcutaneous lymphatic nodes of infected mice with Toxoplasma cruzi, also have shown a significant rise in the numbers of CD4+ and CD8+ lymphocytes ${ }^{[64]}$.

Phosphorylation of NF-kB plays a vital role in maintenance of splenic function and modulation of transcriptional responses that affecting target genes ${ }^{[65]}$. Here, the immune response after oral administration with sarcocysts antigen was characterized by obvious expression of phospho-NF-кB-p65. Also, defects in both static and dynamic splenic architecture of mice in which p65 has been deleted $^{[66]}$. Anatomically, superficial cortex of the lymph node has follicles that homed by B cells. Upon stimulation by infection or immunization, B cells proliferate forming germinal centers and leading to plasma cell production that take the pathway to the medullary cords where they mature producing antibodies into lymph ${ }^{[67]}$. In our results, lymph node immunostaining for $\mathrm{IgG}+$ showed strongly area percent in the cortex while medulla showed weak positivity since cortex contain follicular B cells while medulla contain plasma cells that required to be activated and differentiated. $\mathrm{IgG}$ are the second immunoglobulins to be displayed in toxoplasmosis. Surface antigens of the parasite are the main target antigens for IgG. Moreover, deficient mice in B cells showed no resistance to Toxoplasma gondii, thus enhancing toxoplasmic encephalitis that can be cured by passive transfer of high antibody titers specific for Toxoplasma gondii ${ }^{[68,69]}$. These specific secreted antibodies are dependent on the Th cells-associated cytokines in the lymph nodes during acute toxoplasmosis ${ }^{[70,71]}$.

\section{CONCLUSIONS}

In the present study, there is a discrepancy in the cytokines signature after oral administration of thermally treated or fresh S. fusiformis crude antigen cysts. This antigenic extract of fresh extract induced the positive expression of CD4+ and $\mathrm{CD} 8+\mathrm{T}$ cells number, stimulating their proliferation in the primary and secondary lymphoid organs that evidenced the adaptive immune responses. Induced humoral immune responses in lymph nodes are deduced by positive IgG cells that indicating to $\mathrm{B}$ cell activation. Thereby, killing the parasite did not protect inflammatory immune responses.

\section{ACKNOWLEDGMENT}

The authors appreciate the support of this research by the Science Faculty, Cairo University, Egypt.

\section{CONFLICTS OF INTEREST}

There are no conflicts of interest.

\section{REFERENCES}

1. Dahlgren, S.S.; Gjerde, B. Sarcocystis in moose (Alces alces): molecular identification and phylogeny of six Sarcocystis species in moose, and a morphological description of three new Species. Parasitol. Res. 2008, 103, 93-110. 
2. Lindsay, D.S.; Verma, S.K.; Scott, D.; Dubey, J.P.; Dohlen,A.R.V. Isolation, molecular characterization, and in vitro schizogonic development of Sarcocystis sp. ex Accipiter cooperii from a naturally infected Cooper's hawk (Accipiter cooperii). Parasitol. Int. 2017, 66:106-111.

3. Yang, Z.Q.; Zuo, Y.X.; Yao, Y.G.; Chen, X.W.; Yang, G.C.; Zhang, Y.P. Analysis of the 18S rRNA genes of Sarcocystis species suggests that the morphologically similar organisms from cattle and water buffalo should be considered the same species. Mol. Biochem. Parasitol. 2001, 115, 283-288.

4. Chen, X.W.; Zuo, Y.X.; Rosenthal, B.M.; He, Y.S.; Cui, L.W.; Yang, Z.Q. Sarcocystis sinensis is an ultrastructurally distinct parasite of water buffalo that can cause foodborne illness but cannot complete its lifecycle in human beings. Vet. Parasitol. 2011, 178, 35-39.

5. Lindsay, D.S.; Blagburn, B.L.; Braund, K.G. Sarcocystis spp. and sarcocystosis. BAM 1995, 5(3), 249-254.

6. Kasper, L.H.; Buzoni-Gatel, D. Ups and downs of mucosal cellular immunity against protozoan parasites. Infect. Immun. 2001, 69(1), 1-8.

7. Jacquelot, N.; Luong, K.; Seillet, C. Physiological regulation of innate lymphoid cells. Front. Immunol. $2019,10,405$

8. Eberl, G.; Colonna, M.; Di Santo, J.P.; McKenzie A.N.J. Innate lymphoid cells: A new paradigm in immunology. Science 2015, 348(6237), aaa6566.

9. Ivanova, D.L.; Denton, S.L.; Fettel, K.D.; Sondgeroth, K.S.; Munoz Gutierrez, J.; Bangoura, B.; Dunay, I.R.; Gigley, J.P. Innate lymphoid cells in protection, pathology, and adaptive immunity during apicomplexan infection. Front. Immunol. 2019, 10,196.

10. Pires, B.R.B.; Silva, R.C.M.C.; Ferreira, G.M.; Abdelhay, E. -kappaB: Two sides of the same coin. Genes (Basel) 2018, 9(1), 24.

11. Kumar, H.; Kawai, T.; Akira, S. Pathogen recognition by the innate immune system. Int. Rev. Immun. 2011, 30(1), 16-34.

12. Li, K.; Qu, S.; Chen, X.; Wu, Q.; Shi, M. Promising targets for cancer immunotherapy: TLRs, RLRs, and STING-mediated innate immune pathways. Int. J. Mol. 2017, 18(2), 404.

13. Muñoz-Carrillo, J.L.; Ortega-Martín Del Campo, J.; Gutiérrez-Coronado, O.; Villalobos-Gutiérrez, P.T.; Contreras-Cordero, J.F.; Ventura-Juárez, J. Adipose tissue and inflammation. In: Szablewski L, editor. Adipose Tissue. London: In Tech. 2018, 93-121.
14. Bansal, D.; Ave, P.; Kerneis, S.; Frileux, P.; Boché, O.; Baglin, A.C.; et al. An ex-vivo human intestinal model to study Entamoeba histolytica pathogenesis. PLoS. Negl. Trop. Dis. 2009, 3(11), e551.

15. Sierra-Puente, R.E.; Campos-Rodríguez, R.; JarilloLuna, R.A.; Muñoz-Fernández, L.; Rodríguez, M.G.; Muñoz-Ortega, M.H.; et al. Expression of immune modulator cytokines in human fulminant amoebic colitis. Parasite Immun. 2009, 31(7), 384-391.

16. Bancroft, J. D.; Stevens, A. Theory and practice of histological techniques, 4th ed. Churchill Livingstone, London. 1996, 276.

17. Dubey, J. P.; Speer, C. A.; Fayer, R. Sarcocystosis of animals and man. CRC press, Boca raton, Florida.1989a

18. Current, W.L. Techniques and laboratory maintenance of Cryptosporidium. In: Dubey JP, Speer CA, Fayer R (eds.) Cryptosporidiosis of man and animals, CRC Press Inc, Boca Raton, 1990, 31-49.

19. Bradford, M. M. A rapid and sensitive method for the quantitation of microgram quantities of protein utilizing the principle of protein-dye binding. Anal Biochem. 1976, 72, 248-254.

20. Dubey, J.P.; Naji, N.; Mowery, J.; Verma, S.; CaleroBernal, R. Identification of macroscopic sarcocysts of sarcocystis cameli from one- humped camel (camelus dromedarius) in Iraq. J. Parasitol. 2017, 103(2),168-169.

21. Fayer, R. Gametogeny of Sarcocystis in cell culture. Science 1972, 175, 65-67.

22. Rommel, M.; Heydorn, A.O.; Gruber, V. BeitragezumLebenszyklus der Sarkosporidien. I. Die Sporozyste von S.tenella in den Fazes der Katze. Berl. Münch. Tierärztl. Wschr. 1972, 85: 101-105.

23. Collier, L.; Balows, A.; Sussman, M. Sarcocystis Isospora and Cyclospora. In: Gransden W.R, editor. Topley and Welson's: Microb. Infect. 1998, 9(5), 319-326.

24. Mehlhorn, H.; Heydorn, A.O. Sarcosporidia (Protozoa, Sporozoa): Life cycle and fine structure. Adv. Parasitol. 1978, 16, 73-92.

25. Dubey, J.P.; Rosenthal, B.M.; Morales, J.A.; Alfaro, A. Morphologic and genetic characterization of Sarcocystis sp. from the African grey parrot, Psittacus erithacus, from Costa Rica. Acta. Parasitol. 2006, 51, 161-168.

26. Abdel-Ghaffar, F.; Heydorn, A.O.; Mehlhorn, H. The fine structure of cysts of Sarcocystis moulei from goats. Parasitol. Res. 1989, 75. 416-418. 
27. Melby, P.C.; Stephens, R.; Dann, S.M. Host defenses to protozoa. In: Rich RR, Fleisher TA, Shearer WT, Schroeder HW, Frew AJ, Weyand CM, editors. Clin. Immun. 2019, 5th ed., London, Elsevier, 425-435.e1.

28. Hunter, C.A.; Subauste, C.S.; Van Cleave, V.H.; Remington, J.S. Production of gamma interferon by natural killer cells from toxoplasma gondii-infected scid mice: regulation by interleukin-10, interleukin-12, and tumor necrosis factor alpha. Infect. Immun. 1994, 62, 2818-2824.

29. Miller, L.S.; Pietras, E.M.; Uricchio, L.H.; Hirano, K.; Rao, S.; Lin, H.; O'Connell, R.M.; Iwakura, Y.; Cheung, A.L.; Cheng, G.; Modlin, R.L. Inflammasome-mediated production of IL-1beta is required for neutrophil recruitment against Staphylococcus aureus in vivo. J. Immunol. 2007, 179(10), 6933-42.

30. Kautz-Neu, K.; Kostka, S. L.; Dinges, S.; Iwakura, Y.; Udey, M. C.; von Stebut, E. IL-1 signaling is dispensable for protective immunity in Leishmaniaresistant mice. Exp. Dermatol.2011, 20: 76-78.

31. Guo, L.; Junttila, I.S.; Paul, W.E. Cytokine-induced cytokine production by conventional and innate lymphoid cells. Trends. Immunol. 2012, 33(12), 598-606.

32. Cai, G.; Kastelein, R.; Hunter, C.A. (2000). Interleukin-18 (IL-18) enhances innate IL-12mediated resistance to Toxoplasma gondii. Infect. Immun. 2000, 68(12), 6932-6938.

33. Sierra-Puente, R.E.; Campos-Rodríguez, R.; JarilloLuna, R.A.; Muñoz-Fernández, L.; Rodríguez, M.G.; Muñoz-Ortega, M.H.; et al. Expression of immune modulator cytokines in human fulminant amoebic colitis. Parasite Immun. 2009, 31(7), 384-391.

34. Armitage, R.J.; Macduff, B.M.; Eisenman, J.; Paxton, R.; Grabstein, K.H. IL-15 has stimulatory activity for the induction of $\mathrm{B}$ cell proliferation and differentiation. J. Immunol. 1995, 154, 483-490.

35. Carson, W.; Ross, M.; Baiocchi, R.; Marien, M.J.; Boiani, S.; Grabstein, K.H.; Caligiuri, M.A. Endogenous production of interleukin 15 by activated human monocytes is critical for optimal production of interferon-gamma by natural killer cells in vitro. J. Clin. Invest. 1995, 96, 2578.

36. Khan, I. A; Matsuura, T.; and Kasper, L. H. Interleukin-12 enhances murine survival against acute toxoplasmosis. Infect. lmmun. 1994, 62. 1639.

37. Gazzinelli, R.T.; Hakim, F.T.; Hieny, S.; Shearer, G.M.; Sher, A. Synergistic role of CD4+ and CD8+ $\mathrm{T}$ lymphocytes in IFN- $\gamma$ production and protective immunity induced by an attenuated Toxoplasma gondii vaccine. J. Immunol. 1991, 146, 86-292.
38. Kennedy, M.K.; Glaccum, M.; Brown, S.N.; Butz, E.A.; Viney, J.L.; Embers, M.; Matsuki,N.; Charrier, K.; Sedger, L.; Willis, C.R.; Brasel, K.; Morrissey, P.J.; Stocking, K.; Schuh, J.C.; Joyce, S.; Peschon, J.J. Reversible defects in natural killer and memory CD8 T cell lineages in interleukin 15-deficient mice. J. Exp. Med. 2000, 6,191(5), 771-780.

39. De Rham, C.; Ferrari-Lacraz, S.; Jendly, S.; Schneiter, G.; Dayer, J.M.; Villard, J. The proinflammatory cytokines IL-2, IL-15 and IL21 modulate the repertoire of mature human natural killer cell receptors. Arthritis Res. Ther. 2007, 9(6), R125.

40. Gazzinelli, R.T.; Hieny, S.; Wynn, T.A.; Wolf, S.; Sher, A. Interleukin 12 is required for the T-lymphocyte-independent induction of interferon gamma by an intracellular parasite and induces resistance in T-cell-deficient hosts. Proc. Natl. Acad. Sci. USA. 1993, 90(13): 6115-6119.

41. Hunter, C.A.; Subauste, C.S.; Van Cleave, V.H.; Remington, J.S. (1994). Production of gamma interferon by natural killer cells from toxoplasma gondii-infected scid mice: regulation by interleukin-10, interleukin-12, and tumor necrosis factor alpha. Infect. Immun.1994, 62, 2818-2824.

42. Gafa, V.; Lande, R.; Gagliardi, M.C.; Severa, M.; Giacomini, E.; Remoli, M.E.; et al. Human dendritic cells following Aspergillus fumigatus infection express the CCR7 receptor and a differential pattern of interleukin-12 (IL-12), IL-23, and IL-27 cytokines, which lead to a Th1 response. Infect. Immun. 2006, 74(3), 1480-1489.

43. Cortez, V.S.; Colonna, M. Diversity and function of group 1 innate lymphoid cells. Immunol. Lett. 1999, $179,19-24$.

44. Lauwerys, B.R.; Renauld, J.C.; Houssiau, F.A. Synergistic proliferation and activation of natural killer cells by interleukin 12 and interleukin 18. Cytokine 1999, 11(11), 822-830.

45. Fehniger ,T.A.; Shah, M.H.; Turner, M.J.; VanDeusen, J.B.; Whitman, S.P.; Cooper, M.A.; Suzuki, K.; Wechser ,M.; Goodsaid, F.; Caligiuri, M.A. Differential cytokine and chemokine gene expression by human NK cells following activation with IL-18 or IL-15 in combination with IL-12: implications for the innate immune response. J. Immunol. 1999, 162(8), 4511-4520.

46. Gessner, A.; Mohrs, K.; Mohrs, M. Mast cells, basophils, and eosinophils acquire constitutive IL-4 and IL-13 transcripts during lineage differentiation that are sufficient for rapid cytokine production. J. Immunol. 2005, 174(2), 1063-1072. 
47. Klein Wolterink, R.G.; Kleinjan, A.; van Nimwegen, M.; Bergen, I.; de Bruijn, M.; Levani, Y.; Hendriks, R.W. Pulmonary innate lymphoid cells are major producers of IL-5 and IL-13 in murine models of allergic asthma. Eur. J. Immunol. 2012, 42(5), 1106-1116.

48. Schuijs, M.J.; Halim, T.Y.F. Group 2 innate lymphocytes at the interface between innate and adaptive immunity. Ann N Y. Acad. Sci. 2018, 1417(1), 87-103.

49. D'Andrea, A.; Rengaraju, M.; Valiante, N.M.; Chehimi, J.; Kubin, M.; Aste, M.; Chan, S.H.; Kobayashi, M.; Young, D.; Nickbarg, E.; et al. Production of natural killer cell stimulatory factor (interleukin 12) by peripheral blood mononuclear cells. J. Exp. Med. 1992, 1,176(5),1387-1398.

50. Hsieh, C.S.; Macatonia, S.E.; Tripp, C.S.; Wolf, S.F.; O'Garra, A.; Murphy, K.M. Development of TH1 CD4+ T cells through IL-12 produced by Listeria-induced macrophages. Science 1993, 23,260(5107), 547-549.

51. Gazzinelli, R.T.; Wysocka, M.; Hieny, S.; Scharton-Kersten, T.; Cheever, A.; Kuhn, R.; Muller, W.; Trinchieri, G.; Sher, A. In the absence of endogenous IL-10, mice acutely infected with Toxoplasma gondii succumb to a lethal immune response dependent on CD4+ $\mathrm{T}$ cells and accompanied by overproduction of IL-12, IFN-gamma and TNF-alpha. J. immun. 1996, 157(2), 798-805.

52. Guo, X; Stroup, S.E.; Houpt, E. Persistence of Entamoeba histolytica infection in CBA mice owes to intestinal IL-4 production and inhibition of protective IFN-gamma. Mucosal Immun. 2008, 1(2), 139-146.

53. Denkers, E.Y.; Gazzinelli, R.T. Regulation and function of T-cell-mediated immunity during Toxoplasma gondii Infection. Clin. Microbio. Rev. 1998, 569-588.

54. Pearse, G. Normal structure, function, and histology of the thymus. Toxicol. Pathol. 2006, 34, 504-514.

55. Anderson, G.; Jenkinson, E.J. Lymphostromal interactions in thymic development and function. Nat. Rev. Immunol. 2001, 1, 31-40.

56. Elmore, S.A. Enhanced Histopathology of the Thymus. Toxicol. Pathol. 2006, 34(5), 656-665.

57. Mebius, R. E.; Kraal, G. Structure and function of the spleen. Nature Rev. Immun. 2005, 5, 606-616.

58. Allen, C.D.; Okada,T.; Tang, H.L.; Cyster, J.G. Imaging of germinal center selection events during affinity maturation. Science 2007, 315, 528-531.

59. Witonsky, S.G.; Gogal Jr; R. M.; Lindsay, D.S.
Protective Immune response to experimental infection with Sarcocystis Neurona in 57BL/6 Mice. J. Parasitol. 2003, 89 (5), 924-931.

60. Witonsky, S.G.; Gogal, Jr. R.M.; Duncan, R.B.; and Lindsay, D.S. Protective immune response to experimental infection with Sarcocystis neurona in C57BL/6 mice. J. Parasit. 2003, 89(5), 924-931.

61. Humphreys, N.E.; Worthington, J.J.; Little, M.C.; Rice, E.J.; Grencis, R.K. The role of $\mathrm{CD} 8+$ cells in the establishment and maintenance of a Trichuris muris infection. Parasite Immunol. 2004, 26, 187-196.

62. Alberto, F.; Alexandro, R.; Sergio, O.A.; Diamar, C.P.; Ivian, V.; Armando, A.; Regina, R.A.; Joseli, L. Protective effect of a naked DNA vaccine cocktail against lethal toxoplasmosis in mice. Vaccine 2002, 21, 1327-1335.

63. Elsasser, T.H.; Fayer, R.; Rumsey, T.S.; and Hammond, A.C. Plasma and tissue concentration and molecular forms of somatostatin in calves infected with Sarcocystis cruzi. Dom. Anim. Endocrinol. 1990, 7(4), 537-550.

64. Savino, W. The Thymus is a common target organ in infectious diseases. PLoS. Pathog. 2006, 2(6), e62.

65. Christian, F.; Smith, E.L.; Carmody, R.J. The Regulation of NF- $\kappa B$ Subunits by Phosphorylation. Cells. 2016, 5(1), 12.

66. Alcamo, E.; Hacohen, N.; Schulte, L.C.; Rennert, P.D.; Hynes, R.O.; Baltimore, D. Requirement for the NF-kappaB family member RelA in the development of secondary lymphoid organs. J. Exp. Med. 2002, 195, 233-244.

67. Willard-Mack, C.L. Normal structure, function, and histology of lymph nodes. Toxicol. Path. 2006, 34, 409-424.

68. Kang, H.; Remington, J.S.; Suzuki, Y. Decreased resistance of B cell-deficient mice to infection with Toxoplasma gondii despite unimpaired expression of IFN-gamma, TNF-alpha, and inducible nitric oxide synthase. J. Immunol. 2000, 164, 2629-2634.

69. Sayles, P.C.; Gibson, G.W.; Johnson, L.L. B cells are essential for vaccination-induced resistance to virulent Toxoplasma gondii. Infect. Immun. 2000, 68, 1026-1033.

70. Odegard, J.M.; Marks, B.R; DiPlacido, L.D; Poholek, A.C; Kono, D.H; Dong, C.; Flavell, R.A.; Craft, J. ICOS-dependent extrafollicular helper $\mathrm{T}$ cells elicit IgG production via IL 21 in systemic autoimmunity. J. Exp. Med. 2008, 205, 2873-2886.

71. Lee, S.E.; Kim, N.H.; Chae, H.S.; Cho, S.H.; Nam, H.W.; Lee, W.J.; et al. Prevalence of Toxoplasma gondii infection in feral cats in Seoul, Korea. J. Parasitol. 2011, 97(1), 153-155. 


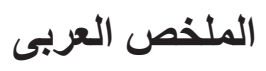

تأثير تناول مستضد الساركوسيستس فوسيفورم على الإستجابات المناعية الفطرية

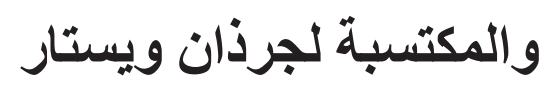

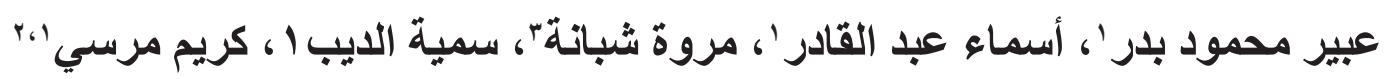

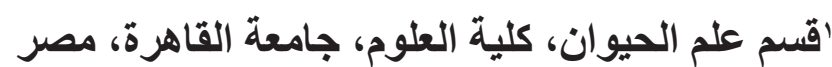

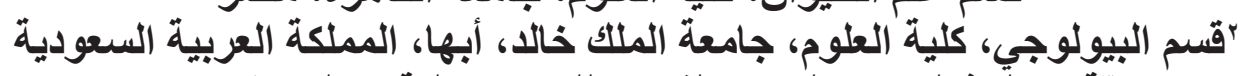

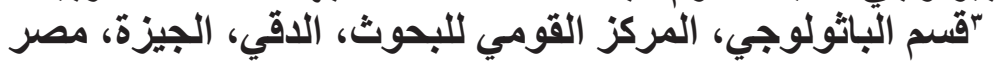

الخلفية: ساركوسيستيس فوسيفورم هو طفيلي أبيليكومبكسان داخل الخلايا يصيب جاموس الماء الهندي ، بوبالس بوباليس ، في مصر. الهدف من العمل: كان الغرض من هذه الدراسة هو تقييم التغيرات في العوامل المناعية لذكور جرذان ويستار بعد تناو لها لمستخلصات ساركوسيستيس المعالجة حر اريا أو الطازجة عن طريق الفم. هنمئ. المواد والطرق: تم عزل الساركوسيستيس من عينات عضلات المريء التي تم جمعها من جواميس الماء الهندي المذبوحة. وقد وصفت هذه الساركوسيستيس شكليا من قبل المجهر الضوئي و الإكتروني. تم تعاطى الجرذان عن طريق الفم (1) الكل مجموعة) كل من: محلول ملحى (المجموعة الضابطة) ، مستخلص أكياس الساركوسيستيس المعالجة حر اريا (المجمو عة الساخنة) أو مستخلص أكياس الساركوسيستيس الطازجة (المجمو عة الطازجة). تم قياس مستويات

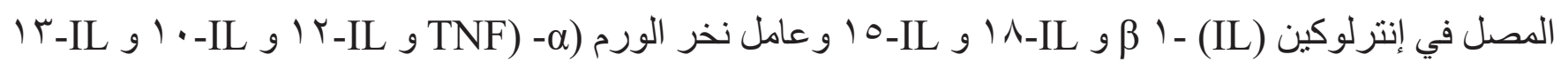

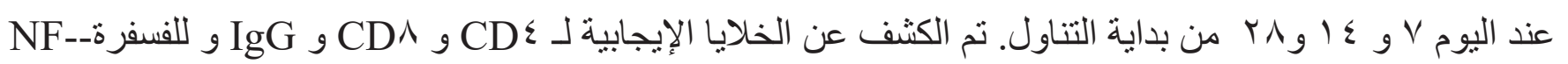
kB بو اسطة تقنية المناعة الكيمائية.

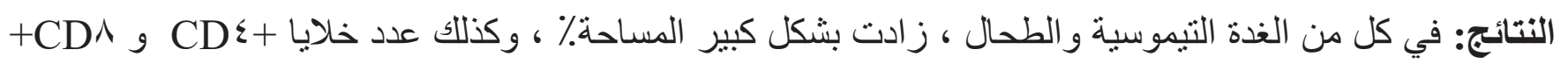
استجابةً للمستخلص الطازج مقارنةً بالمجمو عة الضابطة. في اليوم ^ץ ، تسببت الحالة الطازجة لمستخلص في زيادة

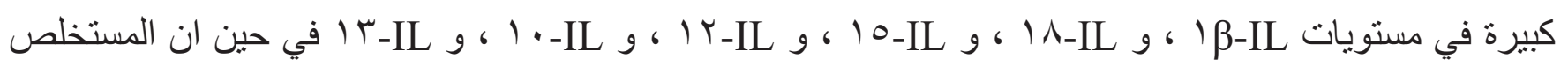

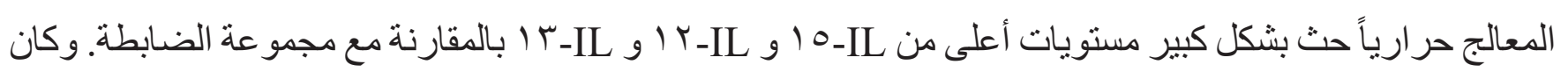
عدد الخلايا الطحالية الموجبة للفسفرة- NF-kB أعلى بكثير في المجمو عة الطازجة عما يوجد فى المجموعة الساخنة او الضابطة. استجابةً للمستخلص الطازج ، تم زيادة عدد خلايا IgG الموجبة بشكل ملحوظ في المنطقة الجر ابية للعقدة الليمفاوية مقارنةً بالضو ابط. الخلاصة: إن الحالة التي يتم فيها تعاطى خلاصة الطفيل (الأكياس الطازجة أو المعالجة حراريا) لها تأثثر متأصل في الاستجابات المناعية ، سو اء الفطرية أو المكتسبة. 